\title{
Seasonal Variation in the Histomorphology and Histochemistry of Ampulla of Vas Deferens of Gaddi Goat and Gaddi Sheep
}

\author{
Variación Estacional en la Histomorfología e Histoquímica de la \\ Ampolla del Conducto Deferente de Cabras y Ovejas Gaddi
}

"Shalini Suri; ** Lakoju Sai Sudhakar \& *** Ram Lal Bhardwaj

SURI, S.; SUDHAKAR, L. S. \& BHARDWAJ, R. L. Seasonal variation in the histomorphology and histochemistry of ampulla of vas deferens of Gaddi goat and Gaddi sheep. Int. J. Morphol., 26(1):131-136, 2008.

SUMMARY: The present study was conducted to record the seasonal variation in the histomorphology and the histochemistry of the ampulla of vas deferens of Gaddi goat and Gaddi sheep, one of the most important breeds of Himachal Pradesh, India. The study was conducted over a period of year during different seasons viz. spring (March - May), summer (June - August), autumn (SeptemberNovember), winter (December-February).Six adult animals of each species were utilized to study histomorphology and histochemical in each season. Ampulla showed distinct three layers viz. tunica mucosa, tunica muscularis and tunica adventitia. Tubulo-alveolar glandular end-pieces (alveoli, tubules and solid end - pieces) were present in the propria-submucosa. The lining epithelium of the tunica mucosa, alveoli and tubules consisted of pseudostratified columnar epithelium. The cojunctive tissue present in between glandular end-pieces consisted of collagen and reticular fibers. The tunica muscularis consisted of two distinct layers (inner circular and outer longitudinal) consisted of mainly smooth muscle fibers, collagen fibers and few reticular fibers in Gaddi goat and sheep. The tunica adventitia consisted of loosely arranged network of collagen, elastic and reticular fibers and occasional autonomic ganglion in Gaddi goat only. The diameter of glandular end-pieces, secretory epithelial height of alveoli and tubules was highest in autumn season and lowest in summer season in both species. Similarly the secretions, apical blebs recorded more in autumn season followed by spring, winter and summer. The secretions and secretory blebs stained intensely for diastase resistant PAS carbohydrates indicating that there may be presence of mucopolysaccharides (other than glycogen as it would have been digested by diastase treatment) that serve the nutrition to ejaculated spermatozoa. The cholesterol was also more in autumn as compared to other seasons in both species. In spring and winter it was more or less same. As the cholesterol is the basic precursor for testosterone.

KEY WORDS: Ampulla vas deferens; Histochemistry; Histomorphology, Gaddi goat; Gaddi sheep.

\section{INTRODUCTION}

The Gaddi goat and Gaddi sheep are important breeds of Himachal Pradesh. They are economically important for the local tribes of Kangra, Kullu, Shimla, Sirmore and Chamba districts of the state. These are migratory breeds. The production, reproduction and behaviour of these breeds depend on the different seasonal conditions prevailing in the area, which in turn are influenced by day and night length. Both species are seasonal breeders. Male animal is the key to the breeding plans so it is important to be well versed with anatomy and physiology of male reproductive organs. Accessory genital glands contribute major part of the semen volume. This study was undertaken to record the variation in the histomorphology and histochemistry of ampulla of the vas deferens of Gaddi goat and Gaddi sheep in different seasons of the year

\section{MATERIAL AND METHOD}

The present study was conducted on the 24 apparently healthy animals of each species (Gaddi goat and Gaddi sheep) of 2- 2.5 years of age. The period of study was divided into four seasons (spring, summer, autumn and winter). In each season, six animals of each species were taken for study.

* Department of Anatomy and Histology, College of Veterinary and Animal Sciences, Associate Professor, FVSc \& AH, SKUAST-J R.S. Pura.

** Department of Anatomy and Histology, College of Veterinary and Animal Sciences, Professor, COVAS, Palampur H.P. India.

${ }^{* * *}$ Department of Anatomy and Histology, College of Veterinary and Animal Sciences, Associate Professor, COVAS, Palampur H.P. India. 
The ampullae of vas deferens were collected, washed with normal saline and fixed in $10 \%$ neutral buffered formalin and $90 \%$ chilled alcohol. The tissues were processed by alcoholbenzene schedule. Paraffin sections of tissues fixed in $10 \%$ neutral buffered formalin was utilized to study histomorphology and alcohol fixed tissues were utilized for carbohydrates (glycogen) study. The sections were stained with H\&E, Verhoeff's counter stained with Von Gieson, Gomori's Reticulum stain, PAS with Diastase and Schultz method for cholesterol (Luna, 1968). For cholesterol demonstration the cryostat sections were cut $(10 \mu)$ by cryostat microtome. Micrometry was done with the help of calibrated ocular micrometer and the micrometric values were analyzed statistically (Snedecor \& Cochran, 1989) and seasonal significance was evaluated. The test of significance was calculated using one way ANOVA followed by Yurkey-Krammer multiple comparison test using Instat-Graph pad software.

\section{RESULTS AND DISCUSSION}

In Gaddi goat and Gaddi sheep the vas deferens showed a distinct ampulla near its termination on reaching the caudal part of the bladder. Raghavan (1964) stated that the dilation was not due to increase in the lumen, but it was due to the increased thickness of the wall caused by the presence of a large number of tubular glands (pars glandularis). Ampulla had distinct three layers i.e. tunica mucosa, tunica muscularis and tunica adventitia (Fig. 1). Trautmann \& Fiebiger (1957) and Dellmann \& Wrobel (1983) described similar layers for ampulla in all domestic animals.

Tunica mucosa showed longitudinal folds. Its surface epithelium was pseudostratified columnar type. Just below the surface epithelium tubulo-alveolar glands were present in the lamina propria-submucosa (Fig. 1). Similar findings were observed in Black Bengal goat, whereas Trautmann \& Fiebiger described branched tubular glands in propria- submucosa of ampulla and they opened on the mucosal surface without special excretory ducts. These glands occupied the entire propria-submucosa. Similar observations were given by Banks (1986) in ruminants. The glandu-

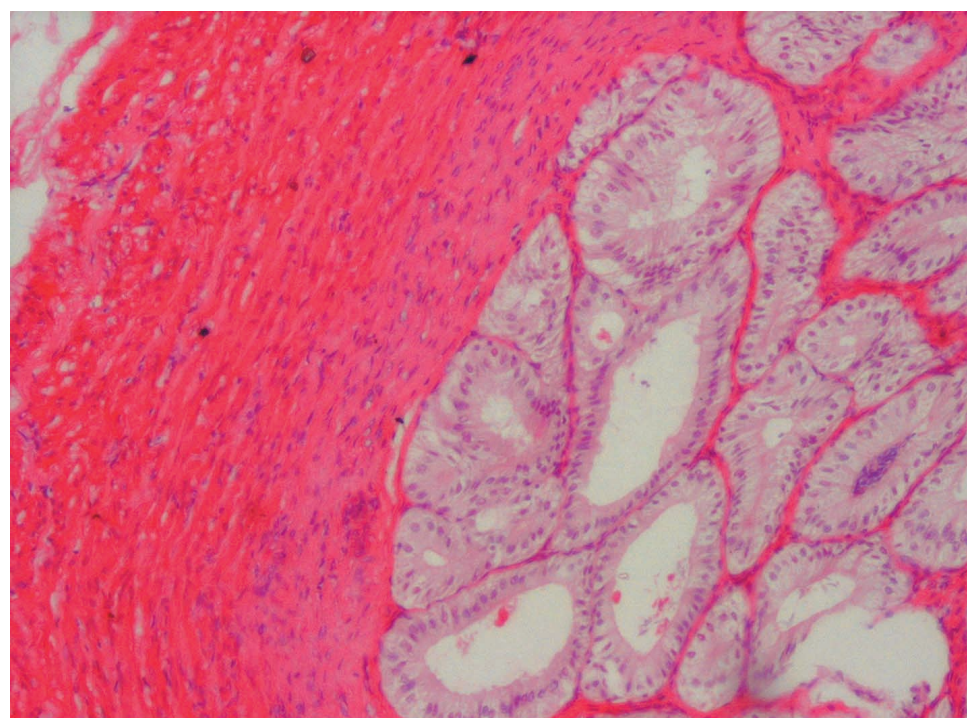

Fig.1.Photomicrograph of ampulla of Gaddi goat showing alveoli (A), tunica muscularis (M) and tunica adventitia (AD). H \& E X 100

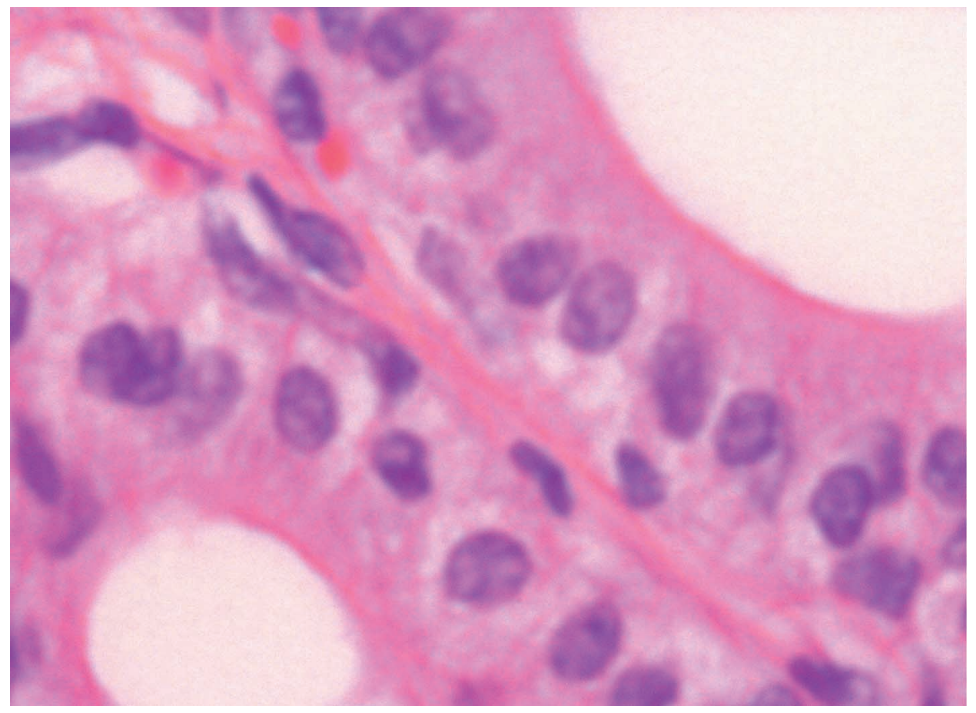

Fig.2.Photomicrograph of ampulla of Gaddi sheep showing basal cells (B) in the lining epithelium of alveoli and tubule. H \& E X 1000.

lar units increased from cranial to caudal portion of the ampulla. This was in contrast with the findings of Sudhakar (2005) in yak.

The propria-submucosa was rich in collagen and reticular fibers. Smooth muscle fibers and elastic fibers were absent as reported in ruminants (Dellmann \& Wrobel) and in goat (Pyne \& Chauhan, 1992). The collagen fibers dominated in number at the junction of submucosa and inner circular muscular layer, the cojunctive tissue extended between glandular end-pieces. The propria submucosa was well vascularized as many small blood vessels were seen. The solid secretory end pieces showed round or elongated nuclei. Sudhakar also reported solid end - pieces in ampulla of yak. The diameter of solid end- pieces measured maximum in autumn season and minimum in summer season 
Table I. Seasonal variation in the micrometry of different components of ampulla of the vas deferens of Gaddi goat. Measurements in microns (Mean $\pm \mathrm{SE})$. Mean values in a row with different superscripts $(\mathrm{a}, \mathrm{b}, \mathrm{c})$ differ significantly $(\mathrm{P}<0.05)$.

\begin{tabular}{ccccc}
\hline Parameters & Spring & Summer & Autumn & Winter \\
\hline Diameter of solid end pieces & $46.80 \pm 1.23$ & $46.20 \pm 2.02$ & $47.76 \pm 1.96$ & $46.78 \pm 1.59$ \\
& $(27.30-71.40)$ & $(27.30-71.40)$ & $(27.30-75.60)$ & $(27.30-71.40)$
\end{tabular}

\section{A) Alveoli}

i) Diameter

ii) Epithelial Height

iii) Nuclear length (E)

iv) Nucl ear breadth (E)

v) Nuclear diameter (R)

\section{B) Tubules}

i) Diameter

ii) Epithelial Height

iii) Nuclear length (E)

iv) Nuclear breadth (E)

v) Nuclear diameter (R)
$109.50 \pm 5.76$
$(79.80-157.50)$

$20.79 \pm 0.65$

(14.70-33.60)

$7.83 \pm 0.23$

(6.30-10.50)

$4.29 \pm 0.03$

(4.20-6.30)

$4.92 \pm 0.17$

(4.20-6.30)

$69.54^{\mathrm{a}} \pm 1.60$

(52.50-84.00)

$18.42^{\mathrm{b}} \pm 0.77$

(12.60-25.20)

$6.75 \pm 0.18$

(6.30-10.50)

$4.26 \pm 0.06$

(4.20-6.30)

$4.44 \pm 0.11$

(4.20-6.30)
$103.50 \pm 5.59$

(84.00-147.00)

$19.94 \pm 0.48$

(12.60-31.50)

$7.44 \pm 0.33$

(6.30-10.50)

$4.26 \pm 0.06$

(4.20-6.30)

$4.80 \pm 0.16$

(4.20-6.30)

$65.46^{\mathrm{a}} \pm 2.51$

(48.30-90.30)

$17.74^{\mathrm{a}} \pm 0.74$

(12.60-23.10)

$6.85 \pm 0.19$

(6.30-10.50)

$4.26 \pm 0.06$

(4.20-6.30)

$4.35 \pm 0.08$

(4.20-6.30)
$110.95 \pm 4.53$

(63.00-147.00)

$21.59 \pm 0.92$

(14.70-33.60)

$8.04 \pm 0.35$

(6.30-10.50)

$4.44 \pm 0.11$

(4.20-6.30)

$5.10 \pm 0.18$

(4.20-6.30)

$71.29^{\mathrm{b}} \pm 2.91$

(52.50-90.30)

$18.51^{\mathrm{b}} \pm 0.98$

(14.70-31.50)

$6.91 \pm 0.15$

(6.30-10.50)

$4.29 \pm 0.03$

(4.20-6.30)

$4.74 \pm 0.16$

(4.20-6.30)
$107.88 \pm 4.97$

(79.80-151.20)

$19.99 \pm 0.47$

(14.70-31.50)

$7.58 \pm 0.23$

(6.30-10.50)

$4.26 \pm 0.06$

(4.20-6.30)

$4.86 \pm 0.16$

(4.20-6.30)

$68.94^{\mathrm{a}} \pm 2.08$

(42.50-94.50)

$18.24^{\mathrm{ab}} \pm 0.53$

(12.60-31.50)

$6.89 \pm 0.36$

(6.30-10.50)

$4.26 \pm 0.06$

(4.20-6.30)

$4.38 \pm 0.18$

$(4.20-6.30)$

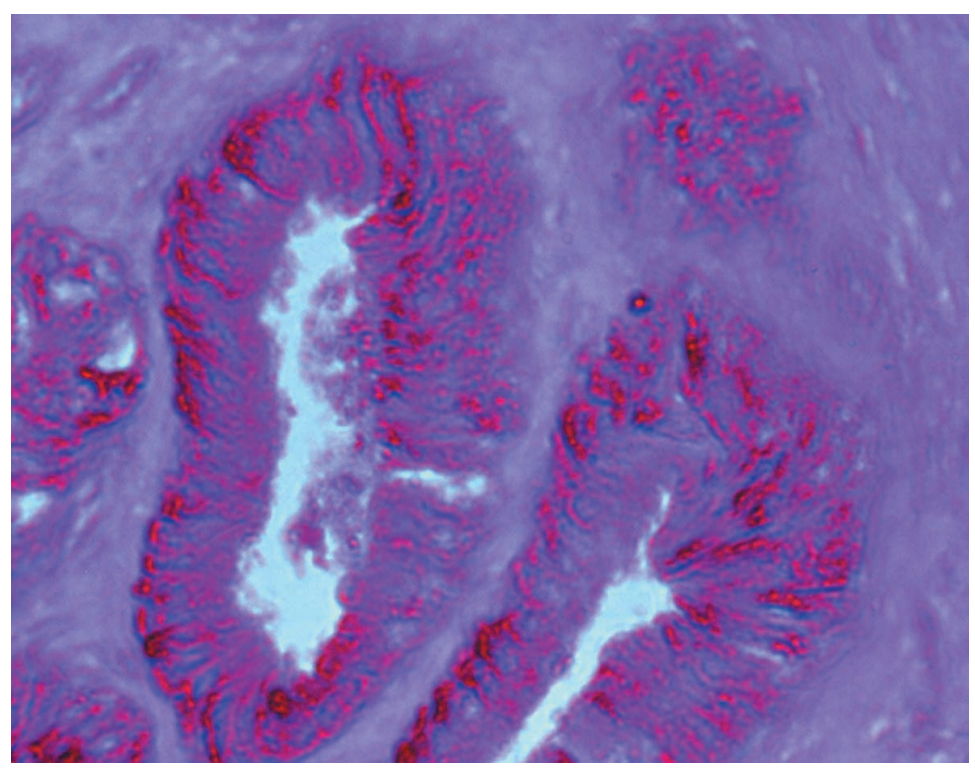

Fig.3.Photomicrograph of ampulla of Gaddi goat showing intensely PAS positive diastase resistant droplets at apical and basal border of lining epithelium of alveoli and in solid end-piece (S) in autumn season. Periodic Acid Schiff's stain X 400 . in Gaddi goat and sheep (Tables I and II, respectively). These solid end - pieces also showed secretory activity, might be under the influence of increased testosterone in breeding season (Hafez, 1993). They stained intensely with PAS, remained resistant to diastase indicating absence of glycogen (Fig. 3). The other carbohydrates present (neutral mucopoly-saccharides) might act as source of energy for spermatozoa. The solid end - pieces reacted mild to moderately for cholesterol. The intensity of cholesterol reactivity was recorded highest in autumn season. In autumn season intensely stained cholesterol droplets were seen in Gaddi goat and Gaddi sheep, might be due to increased production of sex steroids during the breeding season as cholesterol was the precursor for all sex steroids (Donald, 2005).

The alveoli and tubules were lined with pseudostratified columnar epithelium and enclosed a wide lumen (Fig. 1). Dellmann \& Wrobel in small ruminants and Pyne \& Chauhan in goat described 
Table II. Seasonal variations in the micrometry of different components of ampulla of the vas deferens of Gaddi Sheep. Measurements in microns (Mean $\pm \mathrm{SE}$ ). Mean values in a row with different superscripts differ significantly $(\mathrm{P}<0.05)$. Figures in parentheses indicate range. (E) Elongated nucleus and (R) rounded nucleus.

\begin{tabular}{ccccc} 
Parameters & Spring & Summer & Autumn & Winter \\
\hline Diameter of solid end pieces & $50.57 \pm 3.29$ & $45.92 \pm 1.89$ & $56.42 \pm 1.89$ & $48.13 \pm 4.32$ \\
& $(31.50-88.20)$ & $(31.50-84.00)$ & $(29.40-84.00)$ & $(25.20-73.50)$
\end{tabular}
A) Alveoli
i) Diameter
ii) Epithelial height
iii) Nuclear length (E)
iv) Nuclear breadth (E)
v) Nuclear diameter (R)
$99.71^{\mathrm{b}} \pm 2.44$
(39.90-136.50)
$19.25^{\mathrm{a}} \pm 0.17$
$(12.60-25.20)$
$7.46 \pm 0.30$
(6.30-10.50)
$4.84 \pm 0.16$
(4.20-6.30)
$5.10 \pm 0.18$
(4.20-6.30)
B) Tubules
i) Diameter
ii) Epithelial height
iii) Nuclear length (E)
iv) Nuclear breadth (E)
v) Nuclear diameter (R)
$64.22^{\mathrm{ab}} \pm 0.81$
(42.00-84.00)
$16.97^{\mathrm{b}} \pm 0.52$
(10.50-21.00)
$7.07 \pm 0.22$
(6.30-10.50)
$4.72 \pm 0.11$
(4.20-6.30)
$4.98 \pm 0.17$
(4.20-6.30)

$$
\begin{gathered}
89.81^{\mathrm{a}} \pm 1.71 \\
(42.00-147.00) \\
18.46^{\mathrm{a}} \pm 0.18 \\
(12.60-27.30) \\
7.09 \pm 0.22 \\
(6.30-10.50) \\
4.71 \pm 0.16 \\
(4.20-6.30) \\
5.04 \pm 0.18
\end{gathered}
$$
(42.00-147.00)
(4.20-6.30)

$62.10^{\mathrm{a}} \pm 1.59$
$(42.00-81.90)$
$16.56^{\mathrm{a}} \pm 0.08$
$(10.50-25.20)$
$6.92 \pm 0.27$
$(6.30-10.50)$
$4.69 \pm 0.18$
$(4.20-6.30)$
$4.92 \pm 0.17$
$(4.20-6.30)$
$62.10^{\mathrm{a}} \pm 1.59$
$16.56^{\mathrm{a}} \pm 0.08$
$(10.50-25.20)$
(4.20-6.30)

$$
\begin{gathered}
(14.70-31.50) \\
7.57 \pm 1.18 \\
(6.30-10.50) \\
5.02 \pm 0.10 \\
(4.20-6.30) \\
5.34 \pm 0.18
\end{gathered}
$$$$
102.74^{\mathrm{b}} \pm 1.18
$$
(84.00-147.00)
$20.23^{\mathrm{b}} \pm 0.29$
(4.20-6.30)
$67.65^{\mathrm{b}} \pm 1.02$
(52.50-84.00)
$18.38^{\mathrm{c}} \pm 0.12$
(12.60-27.30)
$7.14 \pm 0.18$
(6.30-10.50)
$4.79 \pm 0.06$
(4.20-6.30)
$5.10 \pm 0.18$
(4.20-6.30)
$93.68^{\mathrm{a}} \pm 2.39$
(31.50-136.50)
$18.95^{\mathrm{a}} \pm 0.54$
$(12.60-25.20)$
$7.19 \pm 0.24$
(6.30-10.50)
$4.80 \pm 0.17$
$(4.20-6.30)$
$5.14 \pm 0.13$
$(4.20-6.30)$
$62.94^{\mathrm{a}} \pm 0.83$
(42.50-84.00)
$16.82^{\mathrm{a}} \pm 0.21$
$(10.50-25.20)$
$6.93 \pm 0.14$
(6.30-10.50)
$4.70 \pm 0.13$
$(4.20-6.30)$
$4.94 \pm 0.16$
$(4.20-6.30)$

columnar or cuboidal type of epithelium with ovoid and spherical nuclei, respectively. Trautmann \& Fiebiger and Banks described simple columnar epithelium in glandular unit and in duct in domestic animals. They further added that the epithelial cells vary in height with their functional stage. In the present investigation epithelial height was maximum in autumn season followed by spring, winter and minimum in summer season in Gaddi goat and sheep (Tables I and II). Basal cells with clear cytoplasm and rounded nucleus were also recorded (Fig. 2) in conformity with the observations of Dellmann \& Wrobel in domestic animals. Pyne \& Chauhan did not record basal cells. The nuclear parameters were recorded higher in autumn season in both species that may indicate active season.

The micrometric data showed that diameter of alveoli was highest in autumn season and lowest in summer season (Tables I and II). This might be due to increased secretory activity under the influence of increased concentration of testosterone. Hafez stated that sexual activity is more in autumn season (fall) and coincided with the sharp rise in plasma testosterone in breeding season. The alveolar and tubular lumen contained eosinophilic masses. The luminal secretions were also reported by Trautmann \& Fiebiger. Sometimes these secretory masses had bluish central and pink peripheral areas with H\&E staining (Fig. 4). This may be due to metachromatic reaction exhibited by sulphated mucopolysaccharides (Bancroft \& Stevens, 1977). These secretions were diastase resistant indicating presence of either neutral mucin or weakly acidic sulphated mucin (Bancroft $\&$ Stevens). These types of secretions were recorded in spring and summer seasons, whereas in autumn season many apical blebs and epithelial cells discharging eosinophilic secretion in the lumen were observed (might indicate release of fresh secretions). Dellmann \& Wrobel also described apical blebs and protrusions suggestive of secretory activity.

These secretions were stained moderately with PAS and remained diastase resistant indicated that the glycogen was absent, but there may be presence of neutral or weakly 


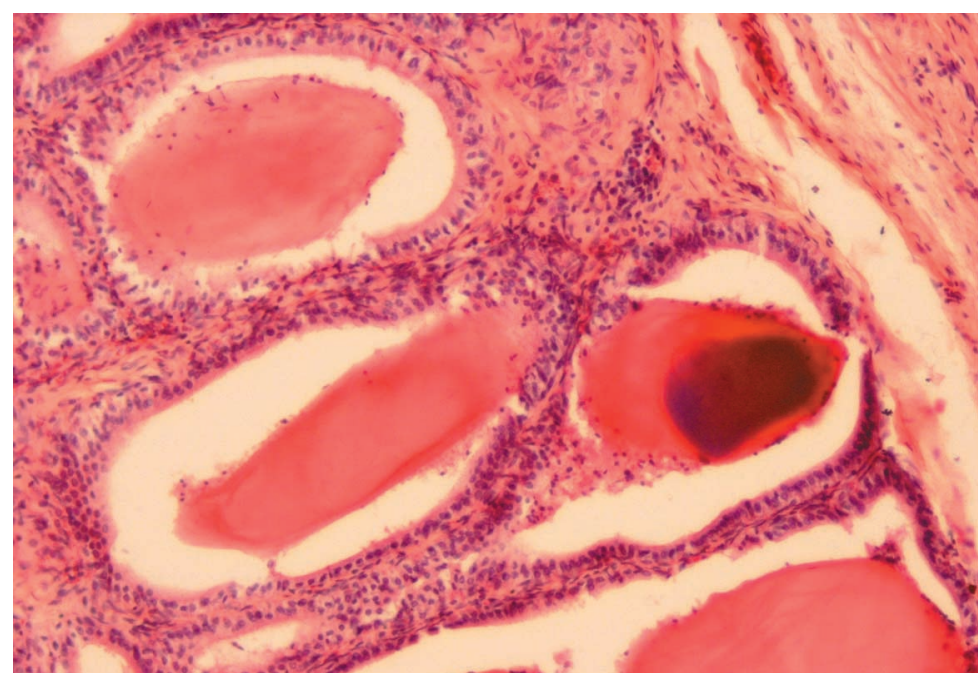

Fig. 4. Photomicrograph of ampulla of Gaddi sheep showing alveoli, tubules filled with heterogenous staining (arrow). H \& E X 100.

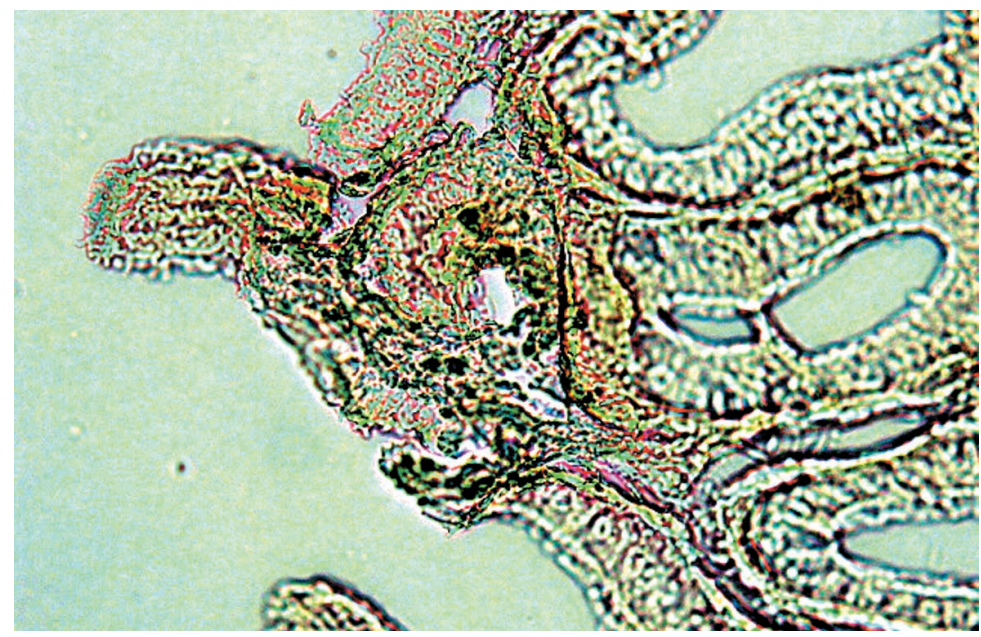

Fig. 5. Cryostat section of ampulla of Gaddi goat showing moderate cholesterol reaction at infranuclear zone. Cholesterol droplets also seen (green coloured) in spring season. Schultz method X 200.

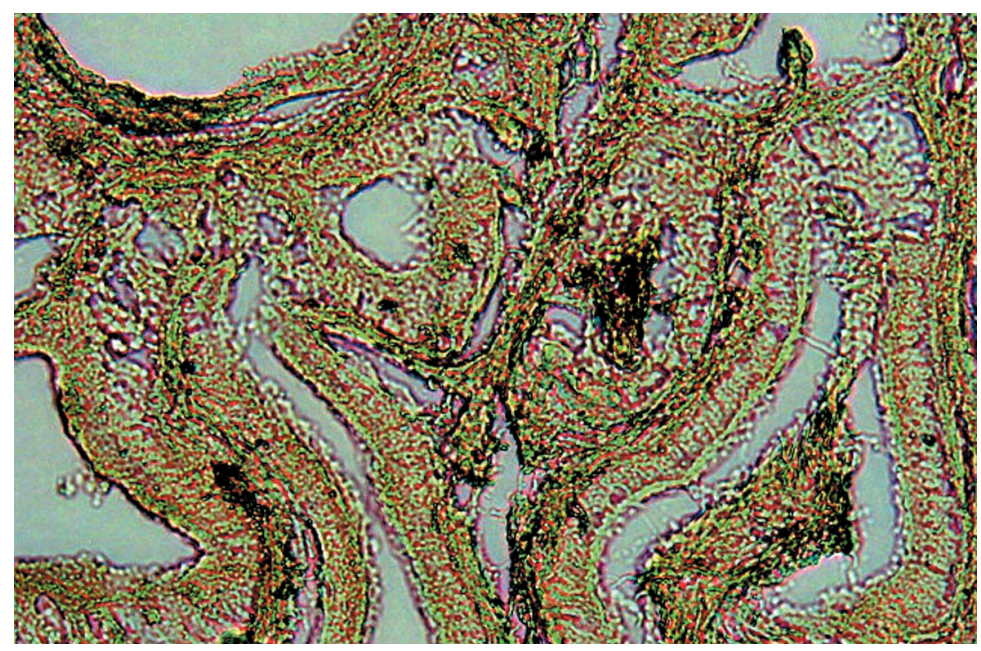

Fig. 6. Cryostat section of ampulla of Gaddi goat showing moderate cholesterol reaction at supra and infranuclear zone. Lumen of alveoli and tubule contain cholesterol positive secretion and sperms in the autumn season (arrows). Schultz method X 200. acidic mucopolysaccharide. Sudhakar observed mild PAS reaction in these secretions in ampulla of yak. The intensely positive cholesterol droplets were seen in Gaddi goat and sheep (Figs. 5 and 6). Other concretions like crystals or stratified secretions were not recorded in ampulla whereas Trautmann \& Fiebiger reported presence of crystals and stratified concretions in ampulla of horses and ruminants.

There was presence of sperms in alveolar and tubular lumen irrespective of season and species. The frequency of occurrence and masses of sperms were more in autumn season (Fig. 6) suggestive of more sexual activity in the autumn season as almost all the lumen were filled with sperms mixed with secretions. This was in agreement with Dellmann \& Wrobel in domestic animals and Pyne \& Chauhan in goat.

Glandular epithelium showed accumulation of PAS -positive diastase resistant granules at apical and basal borders (Fig. 3) which indicated absence of glycogen as the latter would have been digested by diastase whereas Dellmann \& Wrobel described presence of glycogen in glandular epithelium of ampulla of bull. The cholesterol was also present at these borders in both species and in all seasons of the year. In autumn season there was presence of cholesterol droplets at supra and infra nuclear zone (Fig. 6), Dellmann \& Wrobel, Trautmann $\&$ Fiebiger and Banks described the presence of lipid droplets of variable size in bull's glandular epithelium.

Apical blebs indicative of secretory activity were recorded in all seasons in Gaddi goat and Gaddi sheep. This was in agreement with Dellmann \& Wrobel and Pyne \& Chauhan in goat. The frequency of occurrence of apical blebs was recorded highest in autumn season. This might showed the release of fresh secretions and increased secretory activity in this season. The staining intensity of apical blebs varied moderately to intensely for cholesterol (precursor of testosterone) in both species. The apical blebs also stained intensely with PAS, remained diastase resistant, (Fig. 3) reflecting presence of carbohydrates other than glycogen, may be fructose that served the source of nutrition for the ejaculated spermatozoa.

No seasonal variation was recorded in the thickness and contents of tunica muscularis and tunica adventitia of ampulla in both species. 
SURI, S.; SUDHAKAR, L. S. \& BHARDWAJ, R. L. Variación estacional en la histomorfología e histoquímica de la ampolla del conducto deferente de cabras y ovejas Gaddi. Int. J. Morphol., 26(1):131-136, 2008.

RESUMEN: El estudio fue realizado para registrar la variación estacional en la histomorfología y la histoquímica de las ampollas del conducto deferente de cabras y ovejas Gaddi, una de las más importantes razas de pradera del Himalaya, India. El estudio se realizó en un período de un año, en las distintas estaciones. Primavera (marzo-mayo), verano (junio-agosto), otoño (septiembre-noviembre) e invierno (diciembre-febrero). Seis animales adultos de cada especie se utilizaron para el estudio histoquímica e histomorfológico en cada estación. La ampolla mostró tres capas distintas, túnica mucosa, túnica muscular y túnica adventicia. La zona túbulo-alveolar glandular (alvéolos, túbulos y sólidos) estuvieron presente en la submucosa. El epitelio de revestimiento de la túnica mucosa, alvéolos y túbulos consistía en epitelio columnar pseudoestratificado. El tejido conjuntivo presente entre la zona glandular consistió en áreas de colágeno y fibras reticulares. La túnica muscular en las cabras y ovejas, poseía dos estratos (interior circular y exterior longitudinal), que presenta principalmente fibras musculares lisas, fibras colágenas y escasas fibras reticulares. La túnica adventicia presentaba redes de colágeno escasamente organizadas, fibras elásticas y reticulares y, en ocasiones, ganglios autónomos sólo en cabras. El diámetro de los elementos glandulares, la altura del epitelio secretor de los túbulos y alvéolos más altos se registraron en la temporada de otoño y la más baja en temporada de verano, en ambas especies. De igual modo, la secreción de vesículas apicales fueron mayores en la temporada de otoño, seguido de primavera, invierno y verano. Las secreciones y vesículas secretoras fueron teñidas intensamente para PAS diastasa resistente a los hidratos de carbono, que indican que puede haber presencia de mucopolisacáridos (distintos de glucógeno como habría sido digerido por el tratamiento con diastasa) que sirven como nutrientes para los espermatozoides eyaculados. El colesterol aumenta mbién en el otoño, en comparación con otras temporadas, en ambas especies. En la primavera y el invierno es más o menos igual. El colesterol es el precursor básico de la testosterona.

PALABRAS CLAVE: Ampolla del conducto deferente; Histoquímica; Histomorfología; Cabra Gaddi; Oveja Gaddi.

\section{REFERENCES}

Bancroft, J. D. \& Stevens, A. Theory and practices of histochemical techniques. New York, Churchill Livingstone, 1977. p116, 164,195.

Banks, W. J. Applied veterinary histology. $2^{\text {nd }}$ ed. Baltimore, The Williams and Wilkins Company, 1986. pp239-42.

Dellmann, H. D. \& Wrobel, K. H. Male reproductive system. In: Textbook of Veterinary Histology. Dellmann, H. D. \& Brown, E. M. $3^{\text {rd }}$ ed. Philadelphia, Lea \& Feibiger, 1983. pp306-11.

Donald, C. Beitz lipid metabolism. In Dukes' Physiology of Domestic Animals. 12th ed. New Delhi, Panima Publishing Corporation, 2005. p528, 642.

Hafez, E. S. E. Reproduction in farm animals. $6^{\text {th }}$ ed. Philadelphia, Lea \& Febiger, 1993. pp330-6.

Luna, L. G. Manual of histologic methods of the armed forces institute of pathology. $3^{\text {rd }}$ ed. New York, McGraw Hill, 1968. p38, 76, 87, 140.

Pyne, S.K. \& Chauhan, H. V. S. Histomorphological studies of ampulla in goat. Indian J. of Animal Sciences 62(4): 320-1, 1992.

Raghavan, D. Anatomy of ox. New Delhi, Indian Council of Agricultural Research, 1964.
Snedecor, G. \& Cochran, W. Statistical methods. $8^{\text {th }}$ ed. Iowa, University Press, 1989. p503.

Sudhakar, L. S. Histomorphology of the accessory genital glands of yak- A preliminary study. Indian J. Anim. Sci., 75(88):943-4, 2005.

Trautmann, A. \& Fiebiger, J. Fundamentals of histology of domestic animals. Ithaca, Comstock Publishing Associates, 1957.

\author{
Correspondence to: \\ Dr. Shalini Suri \\ Associate Professor \\ Division of Anatomy \\ Faculty of Veterinary Sciences and Animal Husbandry \\ SKUAST - Jammu, R. S. Pura \\ Jammu \& Kashmir \\ INDIA
}

Email: shinsuri1974@gmail.com

Received: 11-06-2007

Accepted: 22-12-2007 